Article

\title{
The Development of Loyalty to Earthen Defensive Heritage as a Key Factor in Sustainable Preventive Conservation
}

\author{
M. Belén Prados-Peña ${ }^{1, * D}$, M. Lourdes Gutiérrez-Carrillo ${ }^{2}$ and Salvador Del Barrio-García ${ }^{1}$ (D) \\ 1 Marketing and Market Research, University of Granada, 18071 Granada, Spain \\ 2 Architectural Constructions, University of Granada, 18071 Granada, Spain \\ * Correspondence: bprados@ugr.es; Tel.: +34958240666
}

Received: 17 May 2019; Accepted: 20 June 2019; Published: 27 June 2019

\begin{abstract}
One of the main risks to the preservation of Spanish defensive heritage is anthropic in origin and is associated with local society's lack of cultural identification with these cultural assets. Consequently, there is a dearth of conservation strategies. In this paper, the current situation is examined, then a management model is proposed, with the Torre de Romilla in the Granada province (Spain) as its focus. The model is constructed on the basis of research regarding the antecedents to loyalty towards this heritage landmark, in order to enhance its value. To accomplish this, survey data from 200 randomly selected subjects was collected and analysed. The results indicate that the antecedent factors which determine loyalty are place attachment and its perceived image, which lead to an increased probability that the site will be visited and recommended. The direct consequence of this is that contributions to the economy from tourism would allow for the sustainable conservation of these assets.
\end{abstract}

Keywords: sustainable tourism; preventive conservation; cultural heritage; brand loyalty; brand image; attachment to place

\section{Introduction}

The earthen defensive heritage of southeast Spain is recognised for its heritage value. As a result, it has been granted the maximum level of protection available under national legislation. However, the fact that these assets are currently in a poor state of conservation is incoherent with this position. The methodological approaches currently being researched centre on proposals for the sustainable preventive conservation of these structures. As part of this approach, and in order to enhance the value of this Cultural Heritage, different perspectives should be considered and how these positions interact should be examined. Specifically, aspects relating to preventive conservation and those associated with the socioeconomic management of the heritage asset need to be considered. Sustainable preventive conservation means that the heritage landmark becomes viewed as a resource which contributes to the socioeconomic growth of the surrounding area. It could be used and developed, it would undoubtedly act as an agent of economic growth, wealth, and employment but it might also be the key factor in the social and economic development of an area (quality of life, feeling of belonging, identity, etc.), which would be of particular importance to areas with limited economic activity. By combining adequate economic management with sustainable management, a portion of the profits generated by the asset could be reinvested into preventive conservation activities.

The design of heritage conservation strategies considers heritage as a resource for economic development, but when it does not receive this attention, the corollary is that it becomes marginalised and destroyed [1]. 
According to [2], public interest or lack of interest in heritage sites is greatly dependent on their state of conservation. It is scientifically accepted that Cultural Heritage assets can contribute as capital goods to socioeconomic development [3], as they have the inherent potential to become tourist attractions, thus contributing to local development [4].

Therefore, leveraging these heritage resources in a sustainable and responsible manner presents an excellent opportunity to improve people's lives, both in terms of material gain (wealth, employment, innovation, entrepreneurship) as well as in nonmaterial ways (identity, participation, training, satisfaction, enjoyment, etc.) [3].

In order to achieve this, most modern societies are committed to and concerned with their heritage worth [2]; as a result, there has been an increase in research in the last few years which approaches heritage appraisal from different perspectives and using different methods [2,5-10]. One perspective that has gained particular attention and relevance is that of consumer-based brand equity, that is, the consumer's appraisal of the brand heritage as regards heritage landmarks.

The American Marketing Association defines a brand as the "name, term, sign, symbol or design, or a combination of them intended to identify the goods and services of one seller or group of sellers and differentiate them from those of other sellers." Brand management is the consequent effort "to create, maintain, protect and improve" [11] a specific brand to ensure a sustainable competitive advantage. As with any brand, those responsible for managing it have an inherent obligation to preserve and improve its reputation and prestige.

In the field of heritage tourism, this translates as guaranteeing the authenticity, integrity, and preservation of the sites and making them available for tourists to visit and enjoy [12], whilst simultaneously taking into account the sustainable development agenda outlined by the World Tourism Organization in 2017 [13]. In fact, the United Nations declared 2017 as the International Year of Sustainable Tourism for Development due to its potential for development worldwide. In the context of brand strategy, heritage landmark, brand management could contribute to tourism growth in a sustainable manner, yet also guarantee conservation of the asset and the best possible outcomes for the local community [13].

Although "brand" has become a buzzword in academia as well as in commercial settings in the last few years, knowledge has concentrated on assets and commercial services and less so on locations and specific tourist destinations [14]. However, in recent years, the strategic needs of destination managers as well as the need to broaden knowledge about the brand's effects have led to the emergence of research on the destination as a brand $[15,16]$.

In the context of tourist destinations, visitor loyalty is considered to be an important factor in the successful development of a destination. Numerous studies carried out in different settings (country, states, city) examine the antecedents to tourist loyalty, including motivation, destination image, quality of travel, perceived value, and satisfaction [17-20]. Place attachment and tourist engagement have also been considered to be predictors of loyalty to the destination [21-23]. More specifically, these predictors have been widely examined in the contexts of leisure and recreational destinations [24] and heritage sites which are established and well-known tourist destinations [25]. According to [4], such heritage resources have the potential to become attractions and contribute to the sustainable development of the area. However, to date, and as far as we know, no studies have been carried out which examine the antecedents of loyalty to heritage sites which are not already established destinations.

Therefore, the main objective of this article is to examine if loyalty to a heritage site arises as a result of the perceived image that individuals have of it, as well as to what degree place attachment mediates the relationship between the effect of image and loyalty. This main objective is supplemented by an analysis of the moderating effect of knowledge about how the heritage site affects these associations.

By so doing, this paper seeks to contribute to the literature on heritage landmark (Goods of Cultural Interest) brand management in several ways. Firstly, further what is currently known about which factors determine loyalty to heritage sites. Secondly, assess the role that perceived image and place attachment plays in developing loyalty to this brand type. Thirdly, examine the degree of 
knowledge about the heritage site as a moderating factor associated with the antecedents to loyalty. As proper management of the brand leads to increased loyalty to the heritage site, it becomes more likely that it will be visited and recommended. The resultant increased income to local communities, especially those with scarce economic resources, in turn facilitates the sustainable management of the heritage asset. All of these factors in turn help to protect and preserve the heritage landmark for future generations.

\section{Background}

\subsection{Heritage Value and Sustainability}

As indicated in [9], cultural economy is being consolidated as a significant discipline within economic analysis, due to both its rich theoretical offering and because it provides an opportunity to gather empirical evidence regarding people's and institutions' behaviour towards modern and accumulated culture. Within the broad analytic spectrum of this new discipline, one aspect making significant contributions to the theory and catalysing its application is the appraisal of cultural assets in general and, in particular, those which are also historical heritage. These authors [9] argue that cultural heritage assets are difficult to appraise for diverse reasons: they are unique and nonreproducible; they are usually public or quasi-public assets; thus, they do not adhere to preconceptions of consumer competition or exclusive offers; finally, the consumer believes that culture is comprised of a collection of necessary assets which the state should maintain, independent of any voluntary contributions.

Along the same lines, the number of studies that estimate the economic value of heritage sites is growing [26]. These authors identify a need for additional academic studies which approach heritage appraisal from an interdisciplinary position, the purpose being to increase what is known about its composition and about the factors which enhance heritage value.

The seminal work of [27] was fundamental in arguing for the importance of cultural heritage due to its effects on employment and productivity. Subsequently, several authors writing in the academic literature have demonstrated that cultural heritage has the capacity to act as a development tool, an engine of economic growth, and to create jobs [2,9,10,28-31], with the caveat that the public's interest in the heritage landmark will depend on its state of conservation [2].

However, recent academic studies suggest that cultural value cannot be solely expressed in terms of economic value, although they are closely correlated [32,33]. The difference is that economic value is commonly defined as individuals' willingness to pay, whereas cultural value refers to additional dimensions such as social value or other nonquantifiable values, such as spiritual, historical, or symbolic. In this sense, the seminal work of [34] provide a novel perspective on cultural heritage as cultural capital, considering it as a vehicle for cultural and economic values. Taking as a premise that cultural heritage can boost development in an area, these authors identify and assess the tools used by the local governments to regulate and support the use of cultural heritage in local development.

According to [35], local communities often conflict over the preservation of tangible and intangible cultural values versus the commercialising of heritage in order to meet consumer demand; consequently, there is no unanimous position on how to strengthen development via cultural heritage preservation. These differences can become polemical if the economic benefits of preserving them are not well understood [26]. In order to avoid these situations, these authors suggest that cultural heritage management is a transversal subject, which should seek a balance between environmental and landscape protection, the marketing of social and cultural elements, and local, sustainable economic development.

It has been argued that tourism has significantly increased economic and social activity and affected the geography of many cities. It provides an opportunity to improve employment and the quality of life in the local community [13]. The International Year of Sustainable Tourism agenda clearly demonstrates its importance to the international community. This agenda has concentrated on five areas: (1) Inclusive and sustainable economic growth; (2) Social inclusiveness, employment, and poverty reduction; (3) Resource efficiency, environmental protection, and climate change; (4) Cultural 
values, diversity, and heritage; (5) Mutual understanding, peace, and security. Within this framework, the following aspects should be highlighted: the need to develop a relationship between tourism and cultural interests which conserves both tangible and intangible cultural heritage; cultural values; pursuing creativity; the provision of social, educational, and economic opportunities. Also important is the development of innovative business models which guarantee sustainable growth in line with market forces.

Therefore, a transversal examination of cultural heritage management requires that heritage managers consider consumer behaviour towards the heritage asset [36]. According to this author, knowing what the client wants and delivering it lies at the core of the cultural heritage marketing process, although prevailing restrictions may need to be taken into account, such as the need to protect parts of a cultural heritage site due to increased wear from higher numbers of visitors responding to marketing promotions. The visitor needs to be satisfied, but not to the detriment of the heritage asset. This must be preserved for future generations, so it is incumbent on heritage managers to seek a balance between commercialising cultural heritage, tourist management, and sustainable practices that will allow heritage to be cared for and conserved [36].

\subsection{Loyalty to the Cultural Heritage}

Brand loyalty can be defined as a client's attachment or commitment to the brand [37]. The academic literature highlights two basic ways to understand consumer loyalty: As an attitude and as a behaviour [38-41]. As an attitude, loyalty is a subjective dimension with cognitive, affective, and conative aspects, since it is these aspects which comprise attitudes $[39,40]$. As a behaviour, loyalty can be understood as a concrete behaviour which is the repeated purchase of the same product or brand or from the same provider, irrespective of whether the consumer has declared any intention to purchase in the future [42-44].

These two approaches therefore consider loyalty to contain two aspects; the consumer's commitment to the brand and repeated brand purchasing behaviour. These approaches are distinct yet compatible, as loyalty is not formed of only either repeat purchase behaviour or commitment, but both, given that loyalty transmutes into a psychological commitment demonstrated by a positive attitude and a genuine intention to purchase again $[39,45]$.

According to [40], loyalty progresses through different stages. These stages are (1) preference (belief) for one brand over another, (2) affective preference (attitude) towards the product, and (3) an increased intention (conation) to purchase one product rather than the competing one. In other words, this progression consists of consumers first becoming loyal in a cognitive manner, with the affective "I like" or "I don't like" coming second, before reaching the final conative stage [46,47].

Loyalty to tourist destinations has been widely studied in the contexts of the aforementioned perspectives. Although [48] has argued that in the context of tourism, studies into loyalty should place a stronger emphasis on behaviour, it has also been argued that researchers in this field have in fact mostly used this approach [49]. Ultimately, however, the benefits that a tourist brings to the tourist destination are simply associated with their return visit behaviour [50]. Their loyalty to the destination is demonstrated as their intention to visit and how likely they are to recommend it $[19,48,51-56]$.

\subsection{Place Attachment}

Research into place attachment across various disciplines has resulted in considerable development of the theory and empirical inquiry. Most conceptualizations of the construct have described it as the range of feelings that individuals associate with specific places [57-59]. Although various terms have been employed to describe it (for example, sense of place, rootedness), most conceptualizations posit affect, emotion, and feeling as fundamental to the concept [60]. However, these authors indicate that emotional aspects are additionally attended by cognitive (thought, knowledge, and belief) and conative (action and behaviour) aspects. Therefore, place attachment implies an interaction between affect and emotion, knowledge and belief, and action and behaviour [57]. 
Aligning with this notion, according to [23], place attachment as a process by which people form emotional bonds with certain sites or places. So, the sense of being physically present and "in place" could be indicative that an individual has formed an emotional bond to a place [23].

Tourism research has extensively addressed the significance and the effect of place attachment [61]. The concept is linked to the process by which an individual's experience of both the physical and social characteristics of a place leads to strong emotional attachments to that place [62] and, as such, is analysed as a multidimensional construct which incorporates two or more dimensions [62-64]. According to [61], the first dimension, place identity, refers to the cognitive link between oneself and a place, reflected as the tourist's identification with a specific place or its symbolic value. The second, place dependence, relates to the functional aspects of place attachment and refers to how a particular place provides for the specific needs and activities of tourists. The third, affective attachment, refers to tourists' feelings about a place. The fourth, social attachment, refers to the social ties reinforced by a specific place. However, for [65], the question of whether place attachment is better described by two or by more components remains to be resolved.

According to [21-23,66-70], place attachment is a significant predictor of tourist loyalty, asserting a direct and positive relationship between attachment to a destination and loyalty towards it.

\subsection{Image of the Cultural Heritage as a Destination}

According to [71] brand image as being the consumer's brand perception, which is held as a memory association. The destination image is widely acknowledged for playing a significant role in tourist behaviour towards it, in particular, when it comes to evaluating, selecting [72-74], deciding to return in future [75,76], thus linking motivation to destination selection [77]. According to [78], tourist perception is of crucial importance as they often select destinations which have the most positive image. If the tourist has constructed a positive image of the destination in their mind, it is likely that they will want to visit $[79,80])$. The seminal work of $[81,82]$ suggest that the perceived image of the destination is the main predictor of the intention to choose a destination. Destination image is defined as the mental representation of knowledge (belief), feelings, and overall perception that an individual has regarding a specific destination [83].

Various researchers $[83,84]$ suggest that any particular destination can be thought of in terms of three image types: organic image, induced image, and complex image. These three image types are based on individuals' experience of a specific destination. An organic image evolves out of nontourist information sources, such as geography books, television reports, or magazine articles. An induced image arises from destination-specific tourist information, such as a brochure or a website; ultimately, it is due to marketing of the destination. The main difference between the organic image and the induced image is in the intention or the motivation to visit. In other words, anyone can have an organic image of a particular destination without intending to visit, whereas those who intentionally seek out information from marketing materials thereby acquire an induced image [84] and do have an intention to visit. Complex image could be the result of the direct experience of a destination [83]. Other authors, such as [85], suggest that destination image developed out of various fields and disciplines concerned with economic, social, or psychological factors, and is a combination of the perceptions or impressions of a tourist destination.

\subsection{Proposed Hypotheses}

Of the different antecedents to the development of loyalty to a destination which are considered by the academic literature, one's own image of the destination should be highlighted. Many studies have found this to be relevant $[17,49,55,86-88]$. The destination image has two significant functions in tourist behaviour: (1) it influences the decision-making process regarding the destination and (2) it conditions subsequent behaviour, including tourists' experience of the place, their assessment of it, and their future behaviour (intention to return and how likely they are to recommend) [17,81]. According to [81], a positive destination image leads to greater satisfaction, an increased intention to return, and 
greater likelihood to recommend. As indicate by [49], the effect that destination image has on tourist loyalty is significant to varying degrees. Specifically, these authors state that the overall image exerts a greater effect on tourist loyalty, followed by affective image and cognitive image.

Taking this into consideration, we propose the following hypothesis:

H1. The greater the perceived image of the heritage site, the greater its loyalty.

On the other hand, place attachment or destination attachment is linked to visitors' loyalty to the place [23] and to their behavioural intent [89]. In the field of tourism study, place attachment is often described as "destination attachment" [23,63]. In the context of rural tourism specifically [89], a significant relationship is found between the tourist's experience, place attachment, and the intention to revisit and recommend. According to [90] individuals' specific place attachment generally begins to develop following one or more visits, although it is possible to develop a strong feeling towards places that they have never visited [91]. In the study of [92], she argues that even tourists who are visiting a place for the first time may already have an attachment to it. This place attachment could possibly be due to having heard stories about the place from friends, family or in the media.

As a result, we propose the following hypothesis:

H2. The greater the degree of place attachment to the heritage site, the greater its loyalty.

The seminal work of [93] underscore the importance of attachment to the destination and the destination image in order to predict tourists' future intentions and behaviour. According to [69], the academic literature suggests that the conceptual bases for place attachment and destination image are similar, since both are constructs with cognitive and affective components that influence behaviour. For these authors, place attachment is an emotional reaction to a physical and social environment, whereas destination image represents the cognitive and affective components connected to a place. On the basis of these assertions, these authors suggest and argue for the idea that destination image is antecedent to place attachment. [94] citing [56] argue that, given that the destination image is a determining factor in tourist attitudes towards the destination, the destination image is antecedent to destination attachment. As show by [94], a more favourable destination image leads to greater attachment to a destination. Consequently, we propose the following hypothesis:

H3. The greater the perceived image of the heritage site, the greater the place attachment to a heritage site.

Alternatively, as defined by [95], consumers' brand knowledge is all the descriptive and evaluative information associated with the brand, as recorded in the consumer's memory. A consumer's knowledge about a product has been considered to be an element that influences all stages of the decision-making process [96], and the academic literature shows that it is considered to have a significant moderating effect on the subject's response $[97,98]$. Consumers with different levels of knowledge about a product also differ in their perceptions of the product $[98,99]$. Consumers who know more about a product have more developed and complex schemas, with well-developed decision-making criteria [100]. In this instance, when consumers process information, it requires less cognitive effort as their knowledge structures are automatically activated and can process more information [101].

In the field of tourism, knowledge about a destination is understood as it being present in people's minds when they are considering it as a travel destination [102]. Assessing awareness of a destination brand is done in terms of examining the selection process by which a specific image is created, and its quality assumed [103,104]. On the basis of antecedent theories regarding the consumer purchase process, including those regarding knowledge about a product, the seminal work of [105] demonstrates that the degree of consumer knowledge about a holiday destination affects the consumer's image of the destination and the probability that they will visit. Similarly, according to [106], by considering familiarity with a destination as much as the degree of knowledge that the tourist has about a destination demonstrates that, in line with [107] and [105], the degree of knowledge influences tourists' perceptions of how attractive the destination is, resulting in a positive effect on place image as well as influencing their level of interest and likelihood of visiting again. 
As a result, we propose the following hypothesis:

H4. Prior knowledge of the heritage site will positively moderate the associations between the antecedents to loyalty.

The proposed hypotheses are summarised in Figure 1.

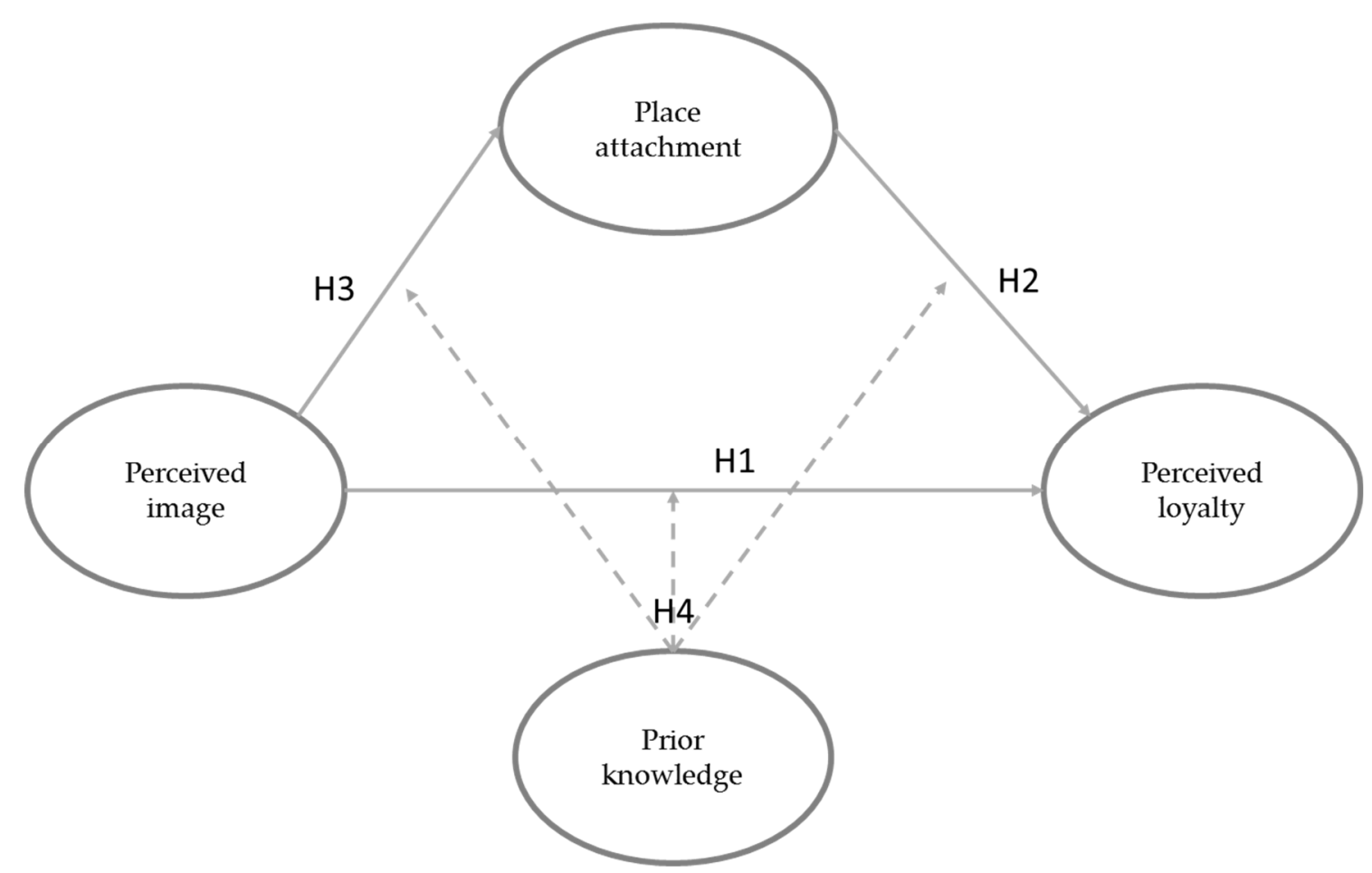

Figure 1. Model for developing loyalty towards the heritage site.

\section{Methodology}

\subsection{Context of Study}

The Torre de Roma heritage site has been chosen for the purposes of this study. This is a tower in a farmstead dating from the Nazari period (fifteenth century), located in the Vega de Granada on irrigated lands, $500 \mathrm{~m}$ from the left bank of the Genil River and next to the town of Romilla in the Chauchina (Granada) municipality.

Its typology is that of a rectangular tower, with base dimensions of $9.45 \mathrm{~m} \times 7.10 \mathrm{~m}$, which gradually narrow as it increases to its current height of $14 \mathrm{~m}$. Currently, access is via the east side, although it is considerably damaged. It has an underground cistern beneath the lower level, which can be accessed via a gap in the northeast corner; however, due to the accumulation of rubble, its depth is not known. It is covered by a half-barrel vault [108] (p. 376).

The lower level was made up of a rectangular room which would have been covered by a barrel vault, of which only the innermost backfill remains. The stairs, no longer present, were located at the north corner and would have provided access to the upper levels. The first floor was made up of a square room next to a corridor and the stairs. The room was covered by a cloister vault. It had loophole windows on the east, west, and south sides, with the main access being on the north side. The last floor contained a rectangular room and a stairwell and was covered by a vaulted ceiling similar to the other rooms. There are also significant openings on the east, west, and southern faces. The tower had a terraced roof on top of the upper vaulted ceiling. Although none remain, the tower might have had a coat of arms and battlements [109]. 
The building technique was lime rammed-earth using formwork boxes with a total height of 82 $\mathrm{cm}$. The building technique for the cistern vault and the bottom level were made without formwork, by plastering the rowlock bricks one on top of the other. This vault building technique required plaster to hold the bricks in place [110].

Its state of conservation is being affected by significant structural damage, which is in turn risking its stability, such as vertical cracks, volumetric loss, and internal stressors, causing a loss of cohesion. Its conservation has also been affected by humidity, occurring as a result of filtration and capillarity in its base. Rainwater splashes have caused significant erosion. On the interior, damage due to decohesion, loss of plastering, sanding, and impairments to supports are notable. Damage to the vaults, flooring, and coverings are also worth mentioning. Other than that which has already been mentioned, there is also damage resulting from inadequate conservation of the cultural asset.

\subsection{Data Collection}

Data was obtained from a survey which was given to a randomly selected sample by the governmental organization responsible for local development in the area where the Torre de Romilla is located. Fieldwork was carried out during January and February of 2018. The final sample was comprised of 200 subjects, with 103 men and 97 women (see Table 1). The age distribution is shown in Table 2.

Table 1. Sample distribution by sex.

\begin{tabular}{ccc}
\hline & Frequency & Percentage \\
\hline Male & 103 & 51.5 \\
Female & 97 & 48.5 \\
\hline Total & 200 & 100 \\
\hline
\end{tabular}

Table 2. Sample distribution by age.

\begin{tabular}{ccc}
\hline & Frequency & Percentage \\
\hline Under 25 years & 50 & 25.0 \\
Between 25 and 40 years & 66 & 33.0 \\
Between 41 and 55 years & 62 & 31.0 \\
More than 55 years & 55 & 11.0 \\
\hline Total & 112 & 100 \\
\hline
\end{tabular}

\subsection{Measures}

The measures used to analyse the constructs have been adapted from existing validated scales (see Table 3). The perceived brand image was measured using a Likert scale with 5 points for 3 items (1, totally disagree; 5, totally agree) and adapted from other studies such as [111]: (1) My image of the Torre de Romilla is good; (2) My image of the Torre de Romilla is positive; (3) My image of the Torre de Romilla is favourable. 
Table 3. Analysis of the psychometric properties of the multi-item scales.

\begin{tabular}{|c|c|c|c|c|c|}
\hline Construct. & Items & $\begin{array}{l}\text { Standardised } \\
\text { Coefficients }\end{array}$ & $\mathbf{R}^{2}$ & CR & AVE \\
\hline \multirow{2}{*}{$\begin{array}{l}\text { Perceived } \\
\text { image }\end{array}$} & $\begin{array}{l}\text { My image of the Torre de Romilla } \\
\text { is positive. }\end{array}$ & $0.87^{* * *}$ & 0.75 & \multirow{2}{*}{0.94} & \multirow{2}{*}{0.85} \\
\hline & $\begin{array}{l}\text { My image of the Torre de Romilla } \\
\text { is favourable. }\end{array}$ & $0.95^{* * *}$ & 0.90 & & \\
\hline \multirow{3}{*}{$\begin{array}{l}\text { Perceived } \\
\text { loyalty }\end{array}$} & $\begin{array}{l}\text { I intend to visit the Torre de } \\
\text { Romilla again if I can. }\end{array}$ & $0.92^{* * *}$ & 0.85 & \multirow{3}{*}{0.95} & \multirow{3}{*}{0.86} \\
\hline & $\begin{array}{l}\text { I will recommend that friends and } \\
\text { family visit the Torre de Romilla. }\end{array}$ & $0.93^{* * *}$ & 0.87 & & \\
\hline & They would be very likely to visit. & $0.94^{* * *}$ & 0.87 & & \\
\hline \multirow{7}{*}{$\begin{array}{l}\text { Place } \\
\text { attachment }\end{array}$} & $\begin{array}{l}\text { It is something that matters to me } \\
\text { a lot. }\end{array}$ & $0.86^{* * *}$ & 0.74 & \multirow{7}{*}{0.97} & \multirow{7}{*}{0.80} \\
\hline & It is of great relevance to me. & $0.91 * * *$ & 0.82 & & \\
\hline & It is of great value to me. & $0.93^{* * *}$ & 0.87 & & \\
\hline & It means a lot to me. & $0.91^{* * *}$ & 0.82 & & \\
\hline & It is very necessary for me. & $0.85^{* * *}$ & 0.73 & & \\
\hline & It is of great interest to me. & $0.90^{* * *}$ & 0.82 & & \\
\hline & $\begin{array}{l}\text { It is something that attracts me a } \\
\text { lot. }\end{array}$ & $0.89 * * *$ & 0.79 & & \\
\hline \multirow{4}{*}{$\begin{array}{c}\text { Prior } \\
\text { knowledge }\end{array}$} & $\begin{array}{l}\text { How knowledgeable do you } \\
\text { consider yourself? }\end{array}$ & $0.88^{* * *}$ & 0.77 & \multirow{4}{*}{0.89} & \multirow{4}{*}{0.74} \\
\hline & Compared to most people, how & & & & \\
\hline & $\begin{array}{l}\text { knowledgeable do you consider } \\
\text { yourself? }\end{array}$ & $0.87^{* * *}$ & 0.76 & & \\
\hline & $\begin{array}{l}\text { How much do you know about } \\
\text { the cultural value of the asset? }\end{array}$ & $0.82^{* * *}$ & 0.68 & & \\
\hline
\end{tabular}

Note: ${ }^{* *} p<0.01$. CR: composite reliability; AVE: average variance extracted.

Loyalty was measured using a Likert scale with 5 points for 3 items (1, totally disagree; 5 , totally agree) and adapted from the suggestion originally made by [112], and then used by other authors as [103,113]): (1) I intend to visit the Torre de Romilla again if I can; (2) I will recommend that friends and family visit the Torre de Romilla; (3) They would be very likely to visit.

For place attachment, a Likert scale of 5 points (1, totally disagree; 5 , totally agree) was used for 7 items adapted from [59,114]: (1) It is something that matters to me a lot; (2) It is of great relevance to me; (3) It is of great value to me; (4) It means a lot to me; (5) It is very necessary for me; (6) It is of great interest to me; (7) It is something that attracts me a lot.

Finally, knowledge was measured using a Likert scale of 5 points (1, nothing; 5 , a lot) for 3 items adapted from [115]: (1) How knowledgeable do you consider yourself? (2) Compared to most people, how knowledgeable do you consider yourself? (3) How much do you know about the cultural value of the asset? In both cases, the items were measured using the Likert scale of 5 points in which 1 indicates "Disagree strongly" and 5 indicates "Agree strongly."

\section{Results}

\subsection{Analysis of the Psychometric Properties of the Scales}

Prior to testing the hypotheses by analysing the data, the psychometric properties of the multi-item scales were examined in order to test for reliability and validity for the constructs they intend to measure. A confirmatory factor analysis (CFA) was carried out using LISREL 8.8 software, the results of which can be seen in Table 3 . The overall goodness-of-fit indices were all within the recommended limits (S-B Chi-Square: 148.83; $p$-value: 0.00; RMSEA: 0.05; CFI: 0.99), all the loadings were significant $(p<0.01)$ with a high magnitude $(>0.70)$, and the values for the individual reliability for each indicator 
$\left(\mathrm{R}^{2}\right)$ were all above the threshold of 0.50 [116]. In addition, in both cases the composite reliability $(\mathrm{CR})$ and average variance extracted (AVE) indices were above the recommended limits of 0.80 and 0.50 , respectively.

On the other hand, using the criterion of [117], we calculated the square root of the AVE and the correlations between the constructs in order to test the discriminant validity. Table 4 shows how, for all cases, the correlations do not exceed the values of the square root of the AVE, confirming its validity.

Table 4. Discriminant validity.

\begin{tabular}{ccccc}
\hline & Knowledge & Attachment & Image & Loyalty \\
\hline Knowledge & $\mathbf{0 . 8 6}$ & & & \\
Attachment & 0.67 & $\mathbf{0 . 8 9}$ & & \\
Image & 0.48 & 0.44 & $\mathbf{0 . 9 2}$ & \\
Loyalty & 0.59 & 0.65 & 0.54 & $\mathbf{0 . 9 3}$ \\
\hline
\end{tabular}

Note: The values of the diagonal (in bold) represent the root of the AVE; the values below the diagonal represent the correlations between the constructs.

These results guarantee the reliability and validity of the multi-item scales, which allowed us to construct an indicator variable, being the mean of the values of the different items of the scale, for each of these constructs.

\subsection{Testing the Hypotheses}

Testing the proposed hypotheses required the use of a moderated mediation regression model via PROCESS 3.1 ordinary least squares and bootstrap estimation (10,000 sub-samples) [118], in order to examine the direct and indirect effects presented in Figure 1. The dependent variable was loyalty to the heritage site, the independent variable was the perceived image of the heritage site, the mediating variable was attachment to the site, and the moderating variable was the tourist's degree of knowledge about the heritage site. The participants' age is included as a covariable

The analysis of direct effects (see Tables 5 and 6 ) shows that both the direct effect of the perceived image of the heritage site on attachment ( $\beta$ Image $\rightarrow$ Attachment: 0.20 ; CI: 0.07-0.33) and of image on loyalty ( $\beta$ Image $\rightarrow$ Loyalty: 0.29; CI: $0.15-0.42)$ were significant $(p<0.01)$. In addition, the direct effect of place attachment on loyalty was significant ( $\beta$ Attachment $\rightarrow$ Loyalty: $0.40 ;$ CI: $0.26-0.53)(p<0.01)$. Therefore, these results confirm $\mathrm{H} 1, \mathrm{H} 2$, and $\mathrm{H} 3$.

Table 5. Moderated mediation analysis Output variable: Place attachment.

\begin{tabular}{ccccccc}
\hline & Coef. & SE & $t$-Value & $p$-Value & \multicolumn{2}{c}{$95 \%$ CI } \\
\hline Constant & -0.18 & 0.16 & -1.13 & 0.26 & -0.49 & 0.13 \\
Perceived image $(X)$ & 0.20 & 0.07 & 2.99 & $0.00 *$ & 0.07 & 0.33 \\
Prior knowledge (W) & 0.62 & 0.07 & 8.87 & $0.00 *$ & 0.48 & 0.75 \\
X x W & -0.01 & 0.06 & -0.16 & 0.87 & -0.13 & 0.11 \\
Age & 0.08 & 0.06 & 1.27 & 0,20 & -0.04 & 0.20 \\
\hline * Coefficient significant at 5\%; 95\% confidence interval does not contain 0.
\end{tabular}

${ }^{*}$ Coefficient significant at $5 \% ; 95 \%$ confidence interval does not contain 0 . 
Table 6. Moderated mediation analysis Output variable: Perceived loyalty.

\begin{tabular}{ccccccc}
\hline & Coef. & SE & $t$-Value & $p$-Value & \multicolumn{2}{c}{$95 \%$ CI } \\
\hline Constant & 3.00 & 0.15 & 19,6 & $0.00 *$ & 2.70 & 3.30 \\
Perceived image $(X)$ & 0.29 & 0.07 & 4.38 & $0.00 *$ & 0.15 & 0.42 \\
Place attachment $(\mathrm{M})$ & 0.40 & 0.07 & 5.73 & $0.00 *$ & 0.26 & 0.53 \\
Prior knowledge $(\mathrm{W})$ & 0.22 & 0.08 & 2.63 & $0.00 *$ & 0.06 & 0.38 \\
X x W & -0.17 & 0.07 & -2.63 & $0.01^{*}$ & -0.30 & -0.04 \\
M x W & 0.02 & 0.06 & 0.32 & 0.75 & -0.10 & 0.13 \\
Age & 0.18 & 0.06 & 3.12 & $0.02^{*}$ & 0.07 & 0.31 \\
\hline
\end{tabular}

${ }^{*}$ Coefficient significant at $5 \% ; 95 \%$ confidence interval does not contain 0 .

$\mathrm{H} 4$ proposes a moderating effect of the tourist's degree of knowledge about the heritage site on the associations between the antecedents to loyalty. To test this, the corresponding interactions need to be examined (see Tables 5 and 6). The results show that, of the three possible interactions, only one is significant, the effect of knowledge on the association between image and loyalty ( $\beta$ Image $x$ Knowledge $\rightarrow$ Loyalty: $-0.17 ; \mathrm{CI}:-0.30-0.04)(p=0.01)$. Figure 2 illustrates the significant effect of this interaction. In this figure, it can be seen that as the subjects' perceived image of the heritage landmark improves, so their loyalty increases, although this effect is reduced as the subjects' degree of knowledge regarding it increases. When the degree of knowledge is small, the effect of image on loyalty is greatly amplified (steep curve), whereas when knowledge regarding the heritage is large, the curve is much flatter. These results only partially confirm $\mathrm{H} 4$ as only the moderating effect was observed to be significant.

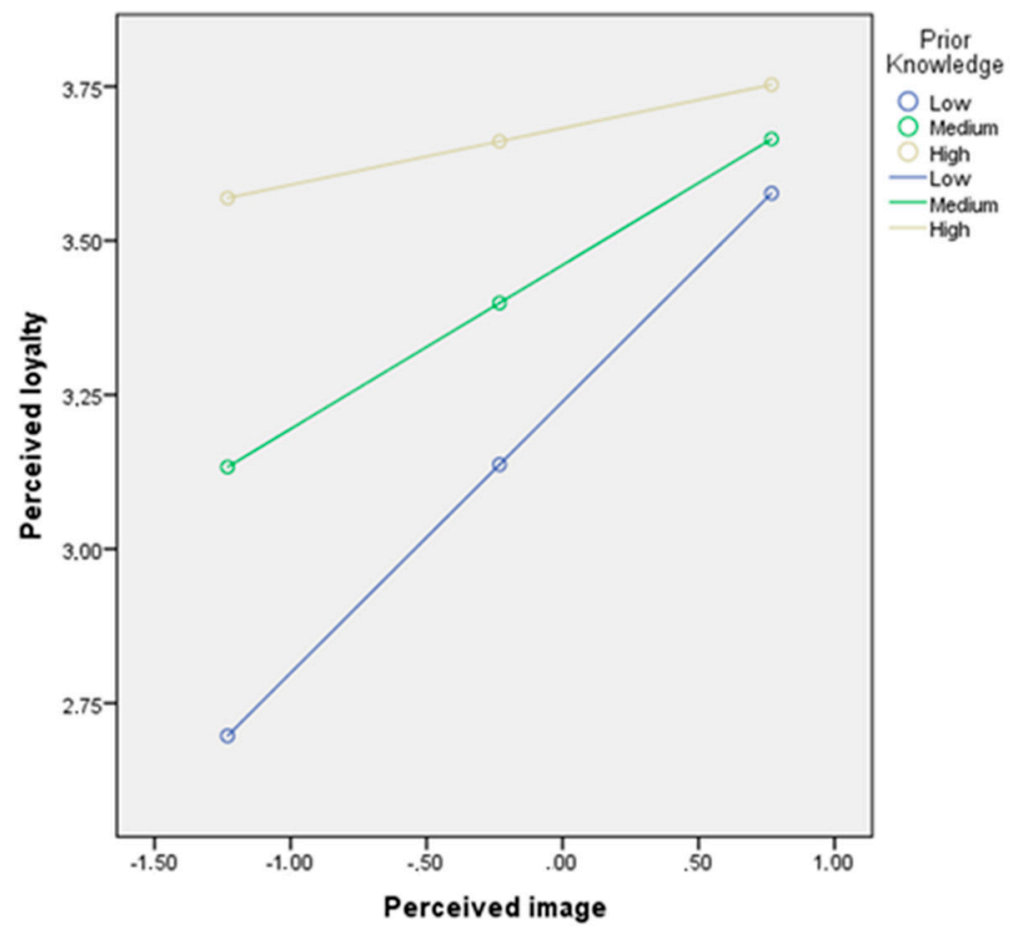

Figure 2. Image on loyalty by knowledge.

PROCESS allows for calculating the conditional indirect effects of the independent variable (image) on the dependent one (loyalty) through the mediating variable (attachment to the heritage site), taking into account the different levels of the moderating variable (knowledge) (see Table 7). The results are of interest as the direct effect of image on loyalty was found to be significant in terms of the conditioning mediating variable but, for the moderating variable, the effect decreases as the degree of knowledge 
about the heritage landmark increases, to the point that when the degree of knowledge is large this effect disappears, becoming nonsignificant $(p>0.05)$.

Table 7. Conditional direct and indirect effects of Image on Loyalty.

\begin{tabular}{ccccc}
\hline \multicolumn{5}{c}{ Conditional Direct Effects } \\
\hline Knowledge & Effect & SE & \multicolumn{2}{c}{$\mathbf{9 5 \% ~ C I ~}$} \\
\hline Low & $0.44^{* * *}$ & 0.09 & 0.27 & 0.61 \\
\hline Medium & $0.26^{* * *}$ & 0.07 & 0.13 & 0.40 \\
\hline High & 0.08 & 0.10 & -0.11 & 0.29 \\
\hline Knowledge & Effect & SE & \multicolumn{2}{c}{$\mathbf{9 5 \% ~ C I ~}$} \\
\hline Low & $0.08^{* *}$ & 0.04 & 0.02 & 0.17 \\
\hline Medium & $0.08^{* *}$ & 0.03 & 0.02 & 0.15 \\
\hline High & $0.08^{* *}$ & 0.05 & 0.00 & 0.20 \\
\hline
\end{tabular}

${ }^{*}$ Non-significant coefficient. 95\% confidence interval includes 0 ** Significant coefficient at $5 \% ; 95 \%$ confidence interval does not contain $0 .{ }^{* *}$ Significant coefficient at $1 \%$; $95 \%$ confidence interval does not contain 0 .

On the other hand, the conditional indirect effects of the image on loyalty mediated by attachment to the patrimonial good are significant $(p<0.05)$ and positive regardless of the degree of knowledge.

\section{Conclusions}

The purpose of this paper is to assess a theoretical model of the development of loyalty to a heritage landmark, on the basis of the perceived image of the heritage site and place attachment to the heritage site. Loyalty to a tourist destination is key to how the tourist behaves with regards to that destination, demonstrated as their intention to visit and how likely they are to recommend it $[48,51,54,55]$. Of the factors which contribute to the development of loyalty to the destination, destination image should be noted $[17,23,49,55,86,88,89]$.

This paper contributes to current understandings of the factors which determine how loyalty to a heritage site is developed and the role played by the degree of knowledge.

In the first place, our findings show that the heritage landmark image has a direct, positive effect on the development of loyalty, and as such, is an antecedent to loyalty towards the destination, in line with the academic literature $[49,55,81]$. In addition, place attachment to the heritage site has a direct, positive effect on the development of loyalty, as has been found by other authors [23,66-70], being antecedent to loyalty. Therefore, increased loyalty is found where there is greater place attachment to the heritage site. Likewise, findings show that image has a direct and positive effect on place attachment to the heritage site, as has previously been asserted [69,94]; therefore, as the image of the heritage asset improves, so place attachment to it increases. An additional conclusion derived from these results and of equal relevance, the association between the perceived image of the Torre de Romilla and place attachment does not appear to be affected by the degree of subjects' prior knowledge about the heritage landmark, counter to what would be expected according to [97]. These results seem to indicate that the link between the heritage landmark and attachment is strong regardless of the degree of knowledge about the heritage site.

In the second place, our findings show that the degree of knowledge regarding the heritage site does in fact moderate the existing direct relationship between the perceived image and loyalty. This is demonstrated by the fact that when there is a small degree of knowledge about the heritage site, the image perceived to it is a greater determinant of loyalty towards it; in this case, loyalty increases as the perceived image of the asset improves. However, in the case of a large degree of knowledge about the heritage site, image is not the determining factor in the development of loyalty to it. The 
results indicate that those who know the Torre de Romilla (either because they have visited or from other sources of information) had a more positive image of the heritage site and were more likely to visit and/or recommend it, in line with [105]. However, counter to the predictions, the effect of place attachment on the association between the asset's perceived image and interest in or likelihood to visit the Torre de Romilla is influenced by the degree of knowledge, contrary to prediction.

\section{Implications for Management}

Our findings also have considerable implications for tourist destination heritage site managers. On the one hand, we have found that a positive perceived image of the heritage site can lead to strong attachment, which paves the way for greater loyalty $[23,63]$. On the other hand, the findings also suggest that, in order to maximally affect loyalty (intention to visit and recommend), managers should take proactive action to increase knowledge about a site, make investments to improve its conservation, and promote the site to a target audience.

Heritage managers should consider all aspects related to such heritage in an integrated manner. As note by [36] citing [119] notes that successful heritage tourism threatens the very heritage resources that are the basis of such tourism. Consequently, these managers' current task is to identify and appropriately respond to strategic opportunities to develop these sites. In line with $[120,121]$, the participation and support of key stakeholders is recommended. Developing practices based on insight, and which are in line with the remit of those responsible for heritage conservation and protection, marketing, and administration, will simultaneously achieve a balance in communication directed towards cultural tourism and tourism in general. Applying marketing techniques and increasing knowledge about the visitors' profiles are essential components of this communication process and go towards ensuring that heritage is accessible and significant for both cultural and general tourism, in line with [120]. Along the same lines, and as is demonstrated by the results, knowledge regarding heritage assets also needs to be increased. As has been shown, greater knowledge leads to greater attachment, which increases the latter's effect on loyalty. These measures would allow the protection and appraisal of cultural heritage to act as a strategic engine for local development [122], without compromising the site's authenticity, as posited by [120].

Therefore, tourist destination planning and management should ensure that special consideration is given to the maintenance and conservation of the natural resources which the tourist offering represents [123]. Improved conservation of the heritage asset will improve its image, which in turn will lead to increased loyalty. This loyalty is demonstrated by the intention to visit and recommend.

This kind of initiative facilitates citizen awareness in a process of cultural identity, as a feeling of esteem for the site patrimonial that promotes its protection and appreciation, by both the local population and the occasional visitor; participants in the defense and maintenance of sites, as well as in compliance with the elementary principles of their conservation [124].

\section{Limitations and Future Lines of Research}

As is the case for any scientific research, the present study presents some limitations worthy of mention. Firstly, this study focuses on presenting a model of the development of loyalty to a specific heritage landmark with the particular characteristics of the "Torre de la Romilla": A heritage site located in the south of Spain, in the Vega de Granada region and not recognized as a tourist destination, but which is nevertheless a resource which has the potential to become one and contribute to local development, as indicated by [4].

The question of whether future studies could replicate the findings of this study for cultural assets with similar characteristics is an interesting one. The findings of this study could be extrapolated for analysis and would potentially have repercussions for assets of a similar nature, characterized by a defensive architecture, located in areas with a population of less than 10,000 inhabitants and disadvantaged from the perspective of the availability of human or material resources. If the potential benefits identified by the present study are taken into account, these considerations taken together 
could lead to improvements in cultural tourism management, general tourism, and the basic social economy of the municipalities and regions in which these heritage landmarks are found

Secondly, a larger simple size would have been preferable; therefore, it is recommended that future studies attempting to replicate this study use larger simple sizes with greater heterogeneity.

Thirdly, future studies should account for other moderating variables such as the subjects' usual residence, their degree of cultural tourism experience, the frequency of visits to these types of cultural landmarks or, as cultural values could be associated with a destination choice or with attachment [125], the visitors' nationality or culture in the case of using samples from other countries.

Author Contributions: Conceptualization, M.B.P.-P. and M.L.G.-C.; methodology, M.B.P.-P.; software, M.B.P.-P.; validation, M.B.P.-P., M.L.G.-C., and S.D.B.-G.; formal analysis, M.B.P.-P.; investigation, M.B.P.-P. and M.L.G.-C.; resources, M.B.P.-P. and M.L.G.-C.; data curation, M.B.P.-P. and M.L.G.-C.; writing-original draft preparation, M.B.P.-P. and M.L.G.-C.; writing-review and editing, M.B.P.-P., M.L.G.-C., and S.D.B.-G.; visualization, M.B.P.-P. and M.L.G.-C.; supervision, S.D.B.-G.; project administration, M.L.G.-C.; funding acquisition, M.L.G.-C.

Funding: This study is part of the project entitled (BIA201569938-R) "Sustainable methodology for the Conservation and Maintenance of medieval rammed-earth fortifications in the South-East of the Iberian Peninsula" financed by the State Research Agency (SRA) and European Regional Development Fund (ERDF).

Acknowledgments: The authors thank the Sierra Elvira Vega Consortium for their collaboration in carrying out the surveys.

Conflicts of Interest: The authors declare no conflict of interest.

\section{References}

1. Malaro, M.C. Museum Governance: Mission, Ethics, Policy; Smithsonian Institution Press: Washington, DC, USA, 1994.

2. Greffe, X. Is heritage an asset or a liability? J. Cult. Herit. 2004, 5, 301-309. [CrossRef]

3. Domínguez-Pérez, M.; Martín-Fernández, J. El patrimonio cultural, recurso estratégico para el enriquecimiento económico y social. Ejemplos desde el patrimonio mundial en España. In Personas y comunidades: Actas del Segundo Congreso Internacional de Buenas Prácticas en Patrimonio Mundial: (29-30 de abril, 1 y 2 de mayo de 2015); Universidad Complutense: Madrid, Spain, 2015; pp. 777-792.

4. Carbone, F. An insight into cultural heritage management of tourism destinations. Eur. J. Tour. Res. 2016, 14, 75-91.

5. Caldwell, N.G. The emergence of museum brands. Int. J. Arts Manag. 2000, 2, 28-34.

6. Camarero, C.; Garrido-Samaniego, M.J.; Vicente, E. Determinants of brand equity in cultural organizations: The case of an art exhibition. Serv. Ind. J. 2012, 32, 1527-1549. [CrossRef]

7. Liu, C.R.; Liu, H.K.; Lin, W.R. Constructing customer-based museums brand equity model: The mediating role of brand value. Int. J. Tour. Res. 2015, 17, 229-238. [CrossRef]

8. Kim, H.; Stepchenkova, S.; Yilmaz, S. Destination Extension: A Faster Route to Fame for the Emerging Destination Brands? J. Travel Res. 2019, 58, 440-458. [CrossRef]

9. Sanz, J.A.; Herrero, L.C. Valoración de bienes públicos relativos al patrimonio cultural. Aplicación comparada de métodos de estimación y análisis de segmentación de demanda. Hacienda Pública Española/Rev. De Econ. Pública 2006, 178, 113-133.

10. Tuan, T.H.; Navrud, S. Capturing the benefits of preserving cultural heritage. J. Cult. Herit. 2008, 9, 326-337. [CrossRef]

11. Kotler, P.; Armstrong, G.; Saunders, J.; Wong, V. Principles of Marketing; Prentice Hall. Inc.: Upper Saddle River, NJ, USA, 2001.

12. Ryan, J.; Silvanto, S. The World Heritage List: The making and management of a brand. Place Branding Public Dipl. 2009, 5, 290-300. [CrossRef]

13. UNWTO. Annual Report, 2017. Available online: https://www2.unwto.org/publication/unwto-annualreport-2017 (accessed on 30 March 2019).

14. Li, X.; Petrick, J.F.; Zhou, Y. Towards a conceptual framework of tourists' destination knowledge and loyalty. J. Qual. Assur. Hosp. Tour. 2008, 8, 79-96. [CrossRef]

15. Cai, L.A. Cooperative branding for rural destinations. Ann. Tour. Res. 2002, 29, 720-742. [CrossRef]

16. Morgan, N.; Pritchard, A.; Pride, R. Destination Branding; Routledge: London, UK, 2007. 
17. Bigné, J.E.; Sanchez, M.I.; Sanchez, J. Tourism image, evaluation variables and after purchase behaviour: Inter-relationship. Tour. Manag. 2001, 22, 607-616. [CrossRef]

18. Chen, C.F.; Tsai, D. How destination image and evaluative factors affect behavioral intentions? Tour. Manag. 2007, 28, 1115-1122. [CrossRef]

19. Chi, C.G.Q.; Qu, H. Examining the structural relationships of destination image, tourist satisfaction and destination loyalty: An integrated approach. Tour. Manag. 2008, 29, 624-636. [CrossRef]

20. Huang, S.; Hsu, C.H. Effects of travel motivation, past experience, perceived constraint, and attitude on revisit intention. J. Travel Res. 2009, 48, 29-44. [CrossRef]

21. Alexandris, K.; Kouthouris, C.; Meligdis, A. Increasing customers' loyalty in a skiing resort: The contribution of place attachment and service quality. Int. J. Contemp. Hosp. Manag. 2006, 18, 414-425. [CrossRef]

22. Hwang, S.N.; Lee, C.; Chen, H.J. The relationship among tourists' involvement, place attachment and interpretation satisfaction in Taiwan's national parks. Tour. Manag. 2005, 26, 143-156. [CrossRef]

23. Yuksel, A.; Fisun, Y.; Yasin, B. Destination attachment: Effects on customer satisfaction and cognitive, affective and conative loyalty. Tour. Manag. 2010, 31, 274-284. [CrossRef]

24. Kyle, G.; Graefe, A.; Manning, R.; Bacon, J. Effect of activity involvement and place attachment on recreationists' perceptions of setting density. J. Leis. Res. 2004, 36, 209-231. [CrossRef]

25. Poria, Y.; Butler, R.; Airey, D. Links between tourists, heritage, and reasons for visiting heritage sites. J. Travel Res. 2004, 43, 19-28. [CrossRef]

26. Wright, W.C.; Eppink, F.V. Drivers of heritage value: A meta-analysis of monetary valuation studies of cultural heritage. Ecol. Econ. 2016, 130, 277-284. [CrossRef]

27. Cwi, D.; Lydall, K. Economic Impact of the Arts and Cultural Institutions: A Model for Assessment and a Case Study in Baltimore; National Endowment for the Arts, Research Division: Washington, DC, USA, 1977.

28. Backman, M.; Nilsson, P. The role of cultural heritage in attracting skilled individuals. J. Cult. Econ. 2016, 42, 111-138. [CrossRef]

29. Bowitz, E.; Ibenholt, K. Economic impacts of cultural heritage. Research and perspectives. J. Cult. Herit. 2008, 10, 1-8. [CrossRef]

30. Llop, M.; Arauzo-Carod, J.M. Economic impact of a new museum on the local economy: "The Gaudí Centre". Lett. Spat. Resour. Sci. 2012, 5, 17-23. [CrossRef]

31. Plaza, B. The return on investment of the Guggenheim Museum Bilbao. Int. J. Urban Reg. Res. 2006, 30, 452-467. [CrossRef]

32. Hutter, M.; Throsby, D. Beyond Price: Value in Culture, Economics, and the Arts; Cambridge University Press: Cambridge, UK, 2008.

33. Throsby, D.; Zednik, A. The economic and cultural value of paintings: Some empirical evidence. In Handbook of the Economics of Art and Culture; Elsevier: Amsterdam, The Netherlands, 2014; Volume 2, pp. 81-99.

34. Kalamarova, M.; Loucanova, E.; Parobek, J.; Supin, M. The support of the cultural heritage utilization in historical town reserves. Procedia Econ. Financ. 2015, 26, 914-919. [CrossRef]

35. Oppio, A.; Bottero, M.; Ferretti, V.; Fratesi, U.; Ponzini, D.; Pracchi, V. Giving space to multicriteria analysis for complex cultural heritage systems: The case of the castles in Valle D'Aosta Region, Italy. J. Cult. Herit. 2015, 16, 779-789. [CrossRef]

36. Misiura, S. Heritage Marketing; Butterworth-Heinemann: Burlington, MA, USA, 2006.

37. Aaker, D.A. Managing Brand Equity Capitalizing on the Value of Brand Name; The Free Press: New York, NY, USA, 1991.

38. Andreassen, T.; Lindestad, B. Customer loyalty and complex services: The impact of corporate image on quality, customer satisfaction and loyalty for customers with varying degrees of service expertise. Int. J. Serv. Ind. Manag. 1998, 9, 7-23. [CrossRef]

39. Dick, A.S.; Basu, K. Customer loyalty: Toward an integrated conceptual framework. J. Acad. Mark. Sci. 1994, 22, 99-113. [CrossRef]

40. Oliver, R.L. Whence consumer loyalty? J. Mark. 1999, 3, 33-44. [CrossRef]

41. Richards, T. Buying loyalty versus building commitment-Developing the optimum retention strategy. Mark. Res. Today 1998, 26, 43-52.

42. Colmenares, O.A.; Saavedra, J.L. Aproximación teórica de la lealtad de marca: Enfoques y valoraciones. Cuad. De Gestión 2007, 7, 69-81. 
43. Delgado-Ballester, M.E. Estado actual de la investigación sobre la lealtad a la marca: Una revisión teórica. Dir. Y Organ. 2004, 30, 16-24.

44. Rodríguez, S.; Camarero, C.; Gutiérrez, J. Lealtad y valor en la relación del consumidor. Una aplicación al caso de los servicios financieros. In Proceedings of the XIV Encuentros Profr. Univ. Mark., Granada, Spain, 9-12 September 2002; pp. 429-443.

45. Vázquez, C.R.; Álvarez, B.Á. Consumers' characteristics and brand choice behaviour: Loyalty and consumption. J. Target. Meas. Anal. Mark. 2007, 15, 121-131. [CrossRef]

46. Back, K.-J. The effects of image congruence on customers' brand loyalty in the upper middle-class hotel industry. J. Hosp. Tour. Res. 2005, 29, 448-467. [CrossRef]

47. Oliver, R.L. Satisfaction: A behavioral Perspective on the Consumer; Routledge: London, UK, 2014.

48. Oppermann, M. Tourism destination loyalty. J. Travel Res. 2000, 39, 78-84. [CrossRef]

49. Zhang, H.; Fu, X.; Cai, L.A.; Lu, L. Destination image and tourist loyalty: A meta-analysis. Tour. Manag. 2014, 40, 213-223. [CrossRef]

50. Almeida-Santana, A.; Moreno-Gil, S. Understanding tourism loyalty: Horizontal vs. destination loyalty. Tour. Manag. 2018, 65, 245-255. [CrossRef]

51. Castro, C.B.; Armario, E.M.; Ruiz, D.M. The influence of market heterogeneity on the relationship between a destination's image and tourists' future behaviour. Tour. Manag. 2007, 28, 175-187. [CrossRef]

52. Chi, C.G.Q. Destination loyalty formation and travelers' demographic characteristics: A multiple group analysis approach. J. Hosp. Tour. Res. 2011, 35, 191-212. [CrossRef]

53. Mohamad, M.; Ali, A.M.; Ab Ghani, N.I. A structural model of destination image, tourists' satisfaction and destination loyalty. Int. J. Bus. Manag. Stud. 2011, 3, 167-177.

54. Pike, S. Destination branding case study: Tracking brand equity for an emerging destination between 2003 and 2007. J. Hosp. Tour. Res. 2010, 34, 124-139. [CrossRef]

55. Polo-Peña, A.I.; Frías-Jamilena, D.M.; Rodríguez-Molina, M.Á. Antecedents of loyalty toward rural hospitality enterprises: The moderating effect of the customer's previous experience. Int. J. Hosp. Manag. 2013, 34, 127-137. [CrossRef]

56. Yoon, Y.; Uysal, M. An examination of the effects of motivation and satisfaction on destination loyalty: A structural model. Tour. Manag. 2005, 26, 45-56. [CrossRef]

57. Kyle, G.; Graefe, A.; Manning, R. Spatial Variation in Level and Type of Place Attachment. In Proceedings of the Northeastern Recreation Research Symposium, EEUU, New York, NY, USA, 28-30 March 2004; pp. $28-30$.

58. Hidalgo, M.C.; Hernandez, B. Place attachment: Conceptual and empirical questions. J. Environ. Psychol. 2001, 21, 273-281. [CrossRef]

59. Williams, D.R.; Patterson, M.E.; Roggenbuck, J.W.; Watson, A.E. Beyond the commodity metaphor: Examining emotional and symbolic attachment to place. Leis. Sci. 1992, 4, 29-46. [CrossRef]

60. Low, S.M.; Altman, I. Place attachment: A conceptual inquiry. In Place Attachment. Colección Human Behavior and Environment: Advances in Theory and Research; Altman, I., Low, S.M., Eds.; Plenum Press: New York, NY, USA, 1992; Volume 12, pp. 1-12.

61. Buonincontri, P.; Marasco, A.; Ramkissoon, H. Visitors' experience, place attachment and sustainable behaviour at cultural heritage sites: A conceptual framework. Sustainability 2017, 9, 1112. [CrossRef]

62. Chen, C.F.; Leask, A.; Phou, S. Symbolic, experiential and functional consumptions of heritage tourism destinations: The case of angkor world heritage site, cambodia. Int. J. Tour. Res. 2016, 18, 602-611. [CrossRef]

63. Ramkissoon, H.; Mavondo, F.T. Proenvironmental behavior: Critical link between satisfaction and place attachment in Australia and Canada. Tour. Anal. 2017, 22, 59-73. [CrossRef]

64. Ramkissoon, H.; Weiler, B.; Smith, L.D.G. Place attachment and pro-environmental behaviour in national parks: The development of a conceptual framework. J. Sustain. Tour. 2012, 20, 257-276. [CrossRef]

65. Ram, Y.; Björk, P.; Weidenfeld, A. Authenticity and place attachment of major visitor attractions. Tour. Manag. 2016, 52, 110-122. [CrossRef]

66. Brocato, E.D. Place attachment: An Investigation of Environments and Outcomes in Service Context. Ph.D. Thesis, The University of Texas at Arlington, Arlington, TX, USA, 2006.

67. George, B.P.; George, B.P. Past visits and the intention to revisit a destination: Place attachment as the mediator and novelty seeking as the moderator. J. Tour. Stud. 2004, 15, 51-66.

68. Kim, S.; Schuckert, M.; Im, H.H.; Elliot, S. An interregional extension of destination brand equity: From Hong Kong to Europe. J. Vacat. Mark. 2017, 23, 277-294. [CrossRef] 
69. Prayag, G.; Ryan, C. Antecedents of tourists' loyalty to Mauritius: The role and influence of destination image, place attachment, personal involvement, and satisfaction. J. Travel Res. 2012, 51, 342-356. [CrossRef]

70. Simpson, P.M.; Siguaw, J.A. Perceived travel risks: The traveller perspective and manageability. Int. J. Tour. Res. 2008, 10, 315-327. [CrossRef]

71. Keller, K.L. Conceptualizing, measuring, and managing customer-based brand equity. J. Mark. 1993, 57, 1-22. [CrossRef]

72. Echtner, C.M.; Ritchie, J.R. The meaning and measurement of destination image. J. Tour. Stud. 2003, 14, 37-48.

73. Gallarza, M.G.; Saura, I.G.; García, H.C. Destination image: Towards a conceptual framework. Ann. Tour. Res. 2002, 29, 56-78. [CrossRef]

74. Hunt, J.D. Image as a factor in tourism development. J. Travel Res. 1975, 13, 1-7. [CrossRef]

75. Hosany, S.; Prayag, G. Patterns of tourists' emotional responses, satisfaction, and intention to recommend. J. Bus. Res. 2013, 66, 730-737. [CrossRef]

76. Zeugner-Roth, K.P.; Vesna, Ž. Bridging the gap between country and destination image: Assessing common facets and their predictive validity. J. Bus. Res. 2015, 68, 1844-1853. [CrossRef]

77. O'Leary, S.; Deegan, J. Ireland's image as a tourism destination in France: Attribute importance and performance. J. Travel Res. 2005, 43, 247-256. [CrossRef]

78. Kim, S.S.; Morrsion, A.M. Change of images of South Korea among foreign tourists after the 2002 FIFA World Cup. Tour. Manag. 2005, 26, 233-247. [CrossRef]

79. Beerli, A.; Martin, J.D. Factors influencing destination image. Ann. Tour. Res. 2004, 31, 657-681. [CrossRef]

80. Bonn, M.A.; Sacha, M.J.; Mo, D. International versus domestic visitors: An examination of destination image perceptions. J. Travel Res. 2005, 43, 294-301. [CrossRef]

81. Lee, T.H. A structural model to examine how destination image, attitude, and motivation affect the future behavior of tourists. Leis. Sci. 2009, 31, 215-236. [CrossRef]

82. Phau, I.; Shanka, T.; Dhayan, N. Destination image and choice intention of university student travellers to Mauritius. Int. J. Contemp. Hosp. Manag. 2010, 22, 758-764. [CrossRef]

83. Fakeye, P.C.; Crompton, J.L. Image differences between prospective, first-time, and repeat visitors to the Lower Rio Grande Valley. J. Travel Res. 1991, 30, 10-16. [CrossRef]

84. Gunn, C.A. Vacationscape: Designing Tourist Regions; Taylor and Francis/University of Texas: Washington DC, USA, 1972.

85. Baloglu, S.; McCleary, K.W. A model of destination image formation. Ann. Tour. Res. 1999, 26, 868-897. [CrossRef]

86. Chi, C.G. An examination of destination loyalty: Differences between first-time and repeat visitors. J. Hosp. Tour. Res. 2012, 36, 3-24. [CrossRef]

87. Martins, M. The tourist imagery, the destination image and the brand image. J. Tour. Hosp. Manag. 2015, 3, 1-14. [CrossRef]

88. Ramseook-Munhurrun, P.; Seebaluck, V.N.; Naidoo, P. Examining the structural relationships of destination image, perceived value, tourist satisfaction and loyalty: Case of Mauritius. Procedia-Soc. Behav. Sci. 2015, 175, 252-259. [CrossRef]

89. Loureiro, S.M.C. The role of the rural tourism experience economy in place attachment and behavioral intentions. Int. J. Hosp. Manag. 2014, 40,1-9. [CrossRef]

90. Moore, R.L.; Graefe, A.R. Attachments to recreation settings: The case of rail-trail users. Leis. Sci. 1994, 16, 17-31. [CrossRef]

91. Chen, C.F.; Phou, S. A closer look at destination: Image, personality, relationship and loyalty. Tour. Manag. 2013, 36, 269-278. [CrossRef]

92. Halpenny, E.A. Environmental Behaviour, Place Attachment and Park Visitation: A Case Study of Visitors to Point Pele National Park. Ph.D. Thesis, University of Waterloo, Waterloo, ON, Canada, 2006.

93. Morais, D.B.; Lin, C.H. Why do first-time and repeat visitors patronize a destination? J. Travel Tour. Mark. 2010, 27, 193-210. [CrossRef]

94. Veasna, S.; Wu, W.Y.; Huang, C.H. The impact of destination source credibility on destination satisfaction: The mediating effects of destination attachment and destination image. Tour. Manag. 2013, 36, 511-526. [CrossRef]

95. Keller, K.L. Understanding brands, branding and brand equity. Interact. Mark. 2003, 5, 7-20. [CrossRef] 
96. Bettman, J.R.; Park, C.W. Effects of prior knowledge and experience and phase of the choice process on consumer decision processes: A protocol analysis. J. Consum. Res. 1980, 7, 234-248. [CrossRef]

97. Alba, J.W.; Hutchinson, J.W. Knowledge calibration: What consumers know and what they think they know. J. Consum. Res. 2000, 27, 123-156. [CrossRef]

98. Baker, T.L.; Hunt, J.B.; Scribner, L.L. The effect of introducing a new brand on consumer perceptions of current brand similarity: The roles of product knowledge and involvement. J. Mark. Theory Pract. 2002, 10, 45-57. [CrossRef]

99. Laroche, M.; Cleveland, M.; Bergeron, J.; Goutaland, C. The Knowledge-Experience-Evaluation Relationship: A Structural Equations Modeling Test of Gender Differences. Can. J. Adm. Sci./Rev. Can. Sci. L'administration 2003, 20, 246-259. [CrossRef]

100. Marks, L.J.; Olson, J.C. Toward a cognitive structure conceptualization of product familiarity. In NA-Advances in Consumer Research; Monroe, K.B., Ed.; Association for Consumer Research: Ann Arbor, MI, USA, 1981; Volume 8, pp. 145-150.

101. Alba, J.W.; Hutchinson, J.W. Dimensions of consumer expertise. J. Consum. Res. 1987, 13, 411-454. [CrossRef]

102. Gartner, W.C. Image formation process. J. Travel Tour. Mark. 1994, 2, 191-216. [CrossRef]

103. Boo, S.; Busser, J.; Baloglu, S. A model of customer-based brand equity and its application to multiple destinations. Tour. Manag. 2009, 30, 219-231. [CrossRef]

104. Yoo, B.; Donthu, N.; Lee, S. An examination of selected marketing mix elements and brand equity. J. Acad. Mark. Sci. 2000, 28, 195-211. [CrossRef]

105. Milman, A.; Pizam, A. The role of awareness and familiarity with a destination: The central Florida case. J. Travel Res. 1995, 33, 21-27. [CrossRef]

106. Mechinda, P.; Serirat, S.; Gulid, N. An examination of tourists' attitudinal and behavioral loyalty: Comparison between domestic and international tourists. J. Vacat. Mark. 2009, 15, 129-148. [CrossRef]

107. Hammitt, W.E.; Backlund, E.A.; Bixler, R.D. Place bonding for recreation places: Conceptual and empirical development. Leis. Stud. 2006, 25, 17-41. [CrossRef]

108. López Guzmán, R. Arquitectura de Al-Andalus (Almería, Granada, Jaén, Málaga); Junta Andalucía/Legado Andalusí/Comares/Fundación Euroarabe: Granada, Spain, 2002.

109. Martín García, M.; Bleda Portero, J.; Martín Civantos, J.M. Inventario de Arquitectura Militar de la Provincia de Granada (S. VIII al XVIII); Diputación: Granada, Spain, 1999; pp. 141-143.

110. Almagro Gorbea, A. La torre de Romilla. Una torre nazarí en la Vega de Granada. Ai-Qantara 1991, XII, 225-250.

111. García, J.A.; Gómez, M.; Molina, A. A destination-branding model: An empirical analysis based on stakeholders. Tour. Manag. 2012, 33, 646-661. [CrossRef]

112. Zeithaml, V.A.; Berry, L.L.; Parasuraman, A. The behavioral consequences of service quality. J. Mark. 1996, 60, 31-46. [CrossRef]

113. Im, H.H.; Kim, S.S.; Elliot, S.; Han, H. Conceptualizing Destination Brand Equity Dimensions from a Consumer-Based Brand Equity Perspective. J. Travel Tour. Mark. 2012, 29, 385-403. [CrossRef]

114. Kyle, G.T.; Absher, J.D.; Graefe, A.R. The moderating role of place attachment on the relationship between attitudes toward fees and spending preferences. Leis. Sci. 2003, 25, 33-50. [CrossRef]

115. Muehling, D.D.; Stoltman, J.J.; Grossbart, S. The impact of comparative advertising on levels of message involvement. J. Advert. 1990, 19, 41-50. [CrossRef]

116. Del Barrio, S.; Luque, T. Análisis de Ecuaciones Estructurales. In Técnicas de Análisis de Datos en Investigación de Mercados; Luque, T., Ed.; Pirámide: Madrid, Spain, 2012.

117. Fornell, C.; Larcker, D.F. Structural equation models with unobservable variables and measurement error: Algebra and statistics. J. Mark. Res. 1981, 18, 382-388. [CrossRef]

118. Hayes, A.F. Introduction to Mediation, Moderation, and Conditional Process Analysis Second Edition: A Regression-Based Approac; The Guilfor Press: New York, NY, USA; London, UK, 2017.

119. Drummond, S.; Yeoman, I. Quality Issues in Heritage Visitor Attractions; Butterworth-Heinemann: Oxford, UK, 2001.

120. Fullerton, L.; McGettigan, K.; Stephens, S. Integrating management and marketing strategies at heritage sites. Int. J. Cult. Tour. Hosp. Res. 2010, 4, 108-117. [CrossRef]

121. Pedersen, A. Managing tourism at world heritage sites. In A Practical Manual for World Heritage Site Managers; ICOMOS: Paris, France, 2002. 
122. Guzmán, P.C.; Roders, A.P.; Colenbrander, B.J.F. Measuring links between cultural heritage management and sustainable urban development: An overview of global monitoring tools. Cities 2017, 60, 192-201. [CrossRef]

123. Bonilla, J.M.L.; Bonilla, L.M.L. Diferencias territoriales en la planificación y la gestión del destino turístico. Cuad. De Tur. 2007, 19, 71-90.

124. Ministry of Education, Culture and Sports. National Plan of Defensive Architecture; General Technical Secretariat: Madrid, Spain, 2015; p. 42.

125. Erdem, T.; Swait, J.; Valenzuela, A. Brands as signals: A cross-country validation study. J. Mark. 2006, 70, 34-49. [CrossRef]

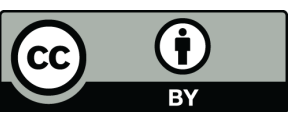

(C) 2019 by the authors. Licensee MDPI, Basel, Switzerland. This article is an open access article distributed under the terms and conditions of the Creative Commons Attribution (CC BY) license (http://creativecommons.org/licenses/by/4.0/). 